\title{
SUOMI-KUVAN UUDET SÄVYT: katsaus Suomi 100 -valtiorahoitusta saaneiden näytelmäelokuvien keskeisiin teemoihin
}

Vuosi 2017 oli Suomen itsenäisyyden satavuotisjuhlavuosi. ${ }^{1}$ Sitä juhlittiin itsenäisyyspäivänä näkyvästi moninaisin Suomi 100 -juhlallisuuksin niin Suomessa kuin maailmalta tulleiden tervehdysten muodossa. Valtioneuvoston retrospektiivin mukaan "maailmasta tuli hetkeksi sinivalkoinen". ${ }^{2}$ Suomi 100 oli kuitenkin laajempi kokonaisuus kuin itsenäisyyspäivän juhlallisuudet. Yksi konkreettinen kokonaisuus olivat erilaisille hankkeille suunnatut valtionavustukset, joita myönnettiin 156 valtakunnalliselle tai kansainväliselle ohjelmahankkeelle, kokonaissumma oli 6834159 euroa. Myös elokuvatuotannoille myönnettiin avustuksia. ${ }^{3}$ Ottaen huomioon näytelmäelokuvien tuotantoprosessin pituuden on selvää, että avustukset myönnettiin jo tuotannossa olleille elokuvahankkeille.

Tarkastelen tässä artikkelissa Suomi 100 -tuettuja näytelmäelokuvia. Niitä on yhdeksän, ja ne ovat kokonaisuutena heterogeeninen joukko teoksia, mutta myös yleisempiä elementtejä on hahmotettavissa. Yksi on historiallisten elokuvien osuus, joita on viisi, ja suurelle osalle niistä on vielä erikseen yhteistä, että sota - Suomen sisällissota ja/tai toinen maailmansota - ovat voimakkaasti läsnä. On mahdoton sanoa, onko kyseessä sattuma liittyen niiden tuotantohetkellä lähestyvään Suomen itsenäisyyden satavuotispäivään, mutta jokainen niistä haluaa selvästi reflektoida aiheidensa kautta jotain suomalaiseen historiatietoisuuteen. Suomen satavuotinen taival itsenäisenä kansakuntana ja valtiona on Suomen pienuuden huomioiden hyvin ymmärrettävästi hallitseva viittauspiste kansalliselle itseymmärrykselle valtakulttuurin tasolla. Voi todeta, että suomalaisuus tarkastelee itseään luontevammin menneisyyden kuin tulevaisuuden kuvittelun kautta.

Toinen vahva motiivi monessa tuotannossa on suomalainen luonto. Muutamissa elokuvissa luonto ei ole vain voimakas visuaalinen miljöö, tapahtumapaikka, vaan ihmiset (ja satuolennot), tapahtumat, kohtalot ovat kuin vain luonnon kiertokulun sattumanvaraisia osasia. Luonto on myös kamppailujen kohde, niin brutaalin sodankäynnin kuin elämäntapojen tasolla. Paradoksaalisesti ilmastotietoisuuden aikakaudella luonto näyttäytyy elokuvissa pikemminkin ajattomana kuin ihmisen muokkaamana. Vaikuttaa siltä, että juuri (suomalainen) luonto on niin keskeinen

\footnotetext{
1 Artikkeli on osa Koneen Säätiön rahoittamaa hanketta Suomen tarinat. Historiakulttuuri, taide ja muuttuva kansalaisuus. Ks. www.suomentarinat.fi. Tarkistettu 5.12.2021.

2 Ks. https://valtioneuvosto.fi/-/10616/suomi-100-juhlavuosi-huipentui-suomessa-ja-maailmalla. Tarkistettu 21.9.2021.

3 Lista kaikista avustetuista hankkeista, alasta riippumatta: https://suomi100raportti.fi/wp-content/ uploads/2018/09/suomi100raportti_liite8_valtionavustukset.pdf. Tarkistettu 30.11.2021.
} 
osa suomalaista identiteettiä, että vain ympäristö ja ilmasto muuttuvat, ei suhde (suomalaiseen) luontoon. Päinvastoin kuin poliittisesti latautunut kansallinen menneisyys, luontosuhde toimii turvapaikkana ristiriitojen ja epävarmojen tulevaisuuskuvitelmien edessä.

Kolmas erottuva piirre ovat sosiaalis-kulttuurinen moninaisuus ja suvaitsevaisuuden eetos, jotka ovat hyvin ajankohtaisia teemoja jokapäiväisellä, arkisella tasolla. Seksuaalisen suuntautumisen ja etnisen taustan teemat ovat niin suoran kuin implisiittisen käsittelyn kohteena, ja elokuvat tukevat oikeutta olla "erilainen" (lainausmerkit siksi, että termi on vaikeasti määriteltävissä yleisellä tasolla) ja "erilaisuuden" arvoa. Vähemmistöjen kaltoinkohtelun esittämisen kautta elokuvat peräänkuuluttavat ennakkoluulottomuutta ja suvaitsevaisuutta. Ne näyttävät pyrkivän puhuttelemaan niin sanottua suurta yleisöä, kuten valtavirran elokuvien luonteeseen on aina kuulunut.

Esittelen kunkin elokuvan tarinan asetelman lyhyesti sekä nostan esiin keskeisiä teemoja ja motiiveja. Käsittelyjärjestys on aakkosellinen (alkaen numeraaleista), jolla tähtään siihen, ettei elokuvien välille synny temaattista tai lajityypillistä hierarkiaa. Mikäli elokuvalle oli luotu mainoslause, mainitsen sen. Lisäksi koostan kustakin elokuvasta avainsanalistan. En varsinaisesti analysoi elokuvia tai niiden juonenkäänteitä, saati pyri luomaan niistä synteesiä, vaan tarkoitukseni on laadullisen sisällönanalyysin menetelmän avulla muodostaa nimenomaan katsaus Suomi 100 -tuettuihin elokuviin ja tarjota lähtökohtia pohdinnalle, millaisia suomalaisuuksia - hyviä, pahoja, "todellisia" tai kuvitteellisia - elokuvissa rakennettiin. ${ }^{4}$

Mainoslause: "Elokuva kiekosta ja kansakunnasta"

Elokuva kertoo tarinan, joka johtaa Suomen jääkiekkomaajoukkueen ensimmäiseen maailmanmestaruuteen keväällä 1995. Se alkaa kertaamalla edeltäneinä vuosikymmeninä koetut katkerat tappiot jääkiekossa Ruotsille. Elokuvassa ei ole varsinaista päähenkilöä, vaikka joukkueen valmistautuminen kuvataan ensi sijassa ruotsalaisen päävalmentaja Curt Lindströmin (Jens Hultén) kautta. Elokuvan representaatio viimeksi mainitusta on hyvin toisenlainen kuin aikanaan ja sittemminkin julkisuudessa, ja toisaalta ruotsalaisten empaattinen ymmärrys mestaruuden merkityksestä suomalaisille nostetaan vahvasti esiin.

Mielenkiintoinen aspekti elokuvassa on, miten laajalti tunnetut kiekkosankarit (Saku Koivu, Ville Peltonen, Timo Jutila ja niin edelleen) esiintyvät elokuvassa näyteltyinä hahmoina, mutta vailla julkisuudesta tunnettuja persoonallisuuksiaan. Sivuosissa vilahtelee puolestaan suomalaisia jääkiekkopersoonia kyseisen mestarijoukkueen pelaajista valmennustiimiin. Tietyssä mielessä elokuva on tältä osin pikemminkin historiallinen toisinto kuin näytelmäelokuva, vaikka sillä on selvät taiteelliset pyrkimyksensä.

Elokuvan vakavina teemoina kulkevat mukana "hurriviha" sekä yksilöllisellä tasolla maalivahti Jukka Tammen asema ja tunteet joukkueen sisällä - Tammi ei pelannut turnauksessa yhtään ottelua, mutta voitti silti maailmanmestauuden joukkueeseen kuuluneena pelaajana. Suomen ja Ruotsin suhdetta kuvataan yhtäältä kansallisten jääkiekkotoimijoiden ja median sekä rivikansalaisten tasolla, tosin vii-

4 Tarkastelen osaa elokuvista tarkemmin tulevissa, edellä mainittuun hankkeeseen sisältyvissä tutkimusartikkeleissani. 
meksi mainittua etupäässä vain suomalaisten näkökulmasta. Elokuvan alleviivattu sanoma on, että Suomi voi olla paras, jos kaikki "pelaavat joukkueelle".

Asiasanat:jääkiekko, maailmanmestaruus, kansallistunne, suomalaisuus, yhteistyö

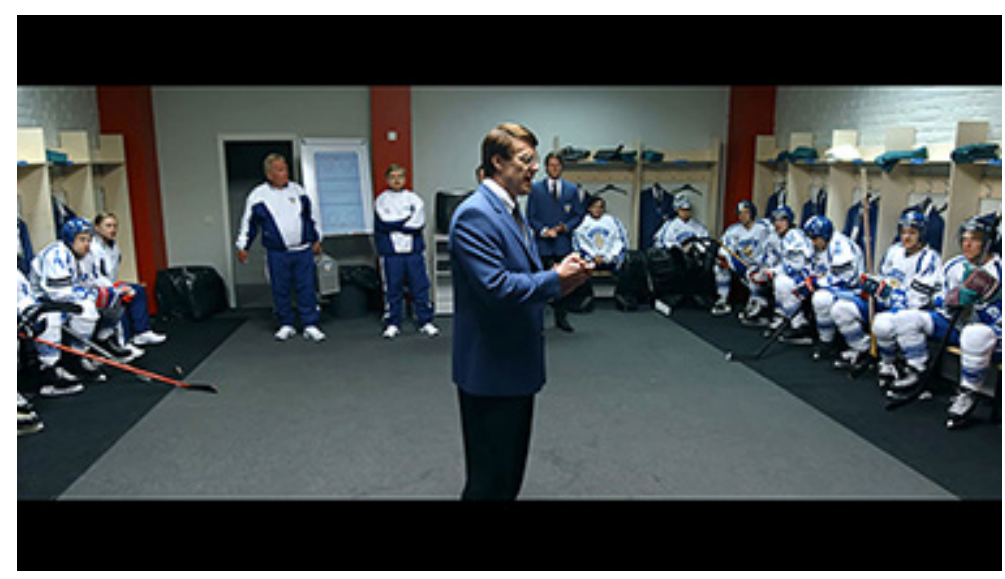

"Tutut" kiekkosankarit valmistautumassa MM-finaaliin elokuvassa 95. Kuvakaappaus DVD:Itä.

\section{Ikitie}

Mainoslause: "Vapaus on taivaan ja helvetin tuolla puolen"

Suomalainen maanviljelijä Jussi Ketola (Tommi Korpela) haetaan kotoaan kommunistiksi syytettynä ja muilutetaan itärajalle 1930-luvun alussa. Hän onnistuu pakenemaan teloitusta rajan yli Neuvostoliittoon. Siellä hänet otetaan avosylin vastaan niin NKVD:n kuin ympäri läntistä maailmaa, erityisesti Yhdysvalloista, saapuneiden kommunistien toimesta. Hän kohtaa yhteisön, jossa jazz soi ja alkoholi virtaa, mutta hilpeän julkisivun alla kytevät kyyninen juonittelu ja vainoharhat sekä lopulta systemaattiset massateloitukset.

Antti Tuurin romaaniin (2011) perustuva elokuva sekä kiinnittyi että lisäsi keskustelua suomalaisten kohtaloista Neuvostoliitossa. Tuurin tuotannon Yhdysvaltainsiirtolaisuus-teema on keskeinen Ikitiessä; suomalaisten valintoja ja tarinoita avataan nimenomaan laajemman siirtolaisuuden ja sosialismin/kommunismin kontekstissa. Oikeastaan päähenkilö Ketola on ainoa "puhtaasti" suomalainen hahmo elokuvassa, ja hän on olosuhteiden ohjailema tarkkailija, ei toimija. Suuri osa elokuvan dialogista on englanniksi, mikä etäännyttää pakolaisten suomalaisuutta alleviivatulla tavalla.

Luonnolla on myös vahva, "suomalainen" rooli elokuvassa, joka sijoittuu kolhoosiin maaseudulle. Luonto on kuitenkin pikemminkin tarkentumaton tausta kuin elävä, monimuotoinen orgaaninen kokonaisuus, kuten useassa muussa Suomi 100

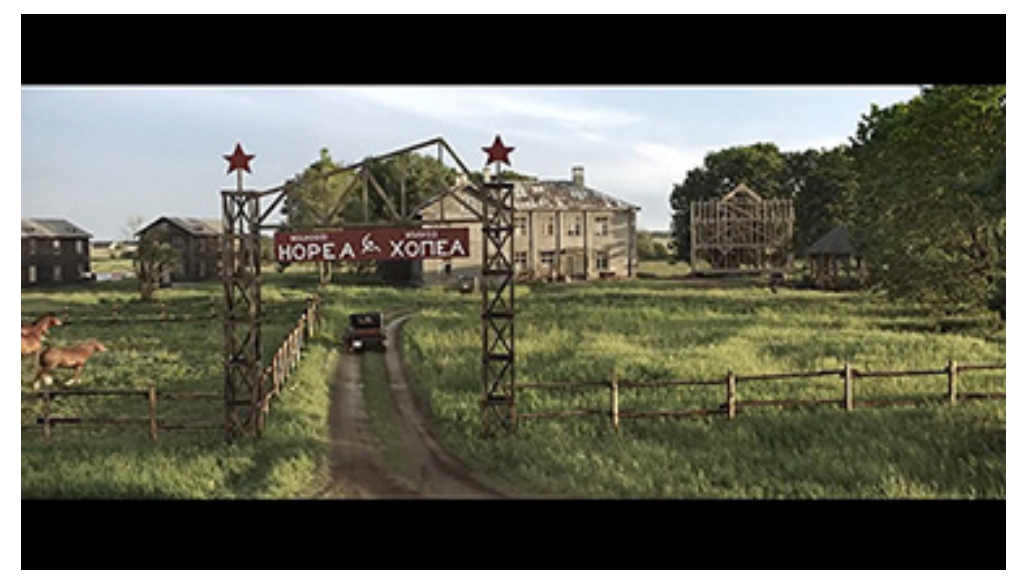

Kolhoosi 1930-luvun alun Neuvosto-Karjalassa elokuvassa Ikitie. Kuvakaappaus DVD:Itä. 
-elokuvassa, mikä on merkittävää: "suomalaisuus" ikään kuin häviää "vieraassa" ympäristössä etäännytetyksi taustakankaaksi. Sen sijaan interiöörejä hallitsevat läsnäolollaan suurikokoiset Stalinin potretit - montaasinomainen rinnastus on varmasti tarkoituksellinen. Tarinaa kehystävä kertojaääni on puolestaan selvästi suunnattu potentiaalisille pohjoisamerikkalaisille, mahdollisesti suomalaiset sukujuuret omaaville yleisöille.

Avainsanat: 1930-luku, Neuvostoliitto, kommunismi, vallankumous, siirtolaisuus

\section{Kuudes kerta}

$$
\begin{array}{r}
\text { Mainoslause: "Elokuva naisesta, joka osasi sanoa kyllä } \\
\text { ja miehestä, joka ei osannut sanoa ei" }
\end{array}
$$

Kuudes kerta on Suomi 100 -tuetuista elokuvista ainoa perinteinen parisuhdedraama, jota 2000-luvun suomalaisen elokuvan tyyliin sävytetään komedialla ja ironisilla leikkauksilla. Elokuvan yhteiskunnallis-sosiaalinen taso koskee tavallisten ihmisten - luksuskiinteistövälittäjän (Antti Luusuaniemi) ja yksityisetsivän (Pihla Viitala) parisuhdekiemuroita. Mies ja nainen tapaavat sattumalta ja päätyvät aloittamaan spontaanin seksisuhteen, vaikka kumpikin on tahoillaan naimisissa. Elokuvaa rytmittävät toistuvat seksikohtaukset, jotka ovat kyltymättömän intohimoista "naimista" valtavirran elokuvaa hallinneen eroottisen, romanttishenkisen rakastelun sijaan.

Taustalla teemoina kulkevat vanhemmuus, elämän perusasioiden rakentaminen (koti ja niin edelleen) sekä eri tavoin paikkaansa yhteiskunnassa etsivien ja sen löytäneiden ratkaisut. Keskeisin teema on kuitenkin päähenkilöiden seksiaddiktioiden tuomat haasteet arkeen sekä halujen toteuttaminen älylaitteiden ja niiden sovellusten avulla - itse asiassa elokuva on yllättäen artikkelissa käsitellyistä ainoa, jossa digitalisaatio ja mobiiliteknologia ovat näkyvästi esillä, mikä tosin selittyy digiaikaa edeltäneiden historiallisten aiheiden suurella osuudella. ${ }^{5}$

Muutamaa kohtausta lukuun ottamatta kyseessä on niin sanottu "Helsinkielokuva", eli miljööt ovat suomalaisessa elokuvassa paljon käytettyä pääkaupungin kivitaloestetiikkaa, kiinnittyen täten pitkään traditioon suomalaisessa elokuvassa. Luonto näyttäytyy ensi sijassa pääkaupunkilaisittain katsoen "kesämökki"-Suomena.

Avainsanat: parisuhde, uskottomuus, seksi, nettideittailu, avioero

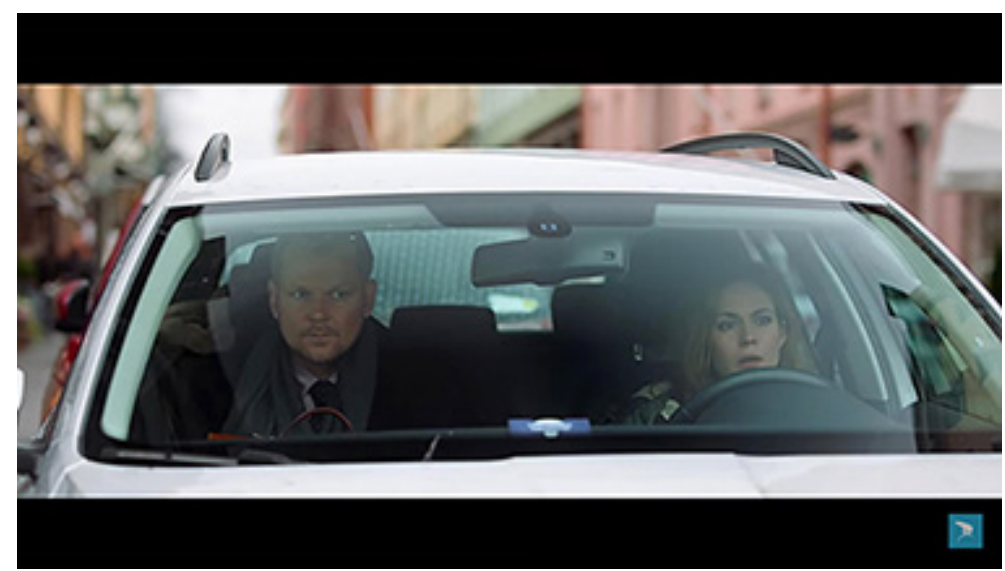

Kuudes kerta kertoo avoimen mutta salaisen seksisuhteen mahdollisuuksista ja uhkista. Kuvakaappaus elokuvan trailerista.

5 Suomi 100 -rahoitusta myönnettiin digiaikaan sijoittuvalle dokumenttielokuvalle Nokia Mobile: matkapuhelimen tarina (Arto Koskinen, 2017). 


\section{Lauri Mäntyvaaran tuuheet ripset}

Elokuvan keskushahmot ovat kaksi prätkillä ajavaa teini-ikäistä aktivistityttöä (Inka Haapamäki ja Rosa Honkonen), jotka taistelevat kapitalismia ja epäaitoa rakkautta vastaan, joskus myös "kepposille" perustuvin "terrori-iskuin". Toinen heistä on kuitenkin ihastunut Lauriin (Tiitus Rantala), lupaavaan jääkiekkoilijanuorukaiseen, jolle povataan menestyksekästä NHL-uraa. Ystävä hyväksyy ystävänsä ihastuksen mutta suhtautuu samalla perinteisiin sukupuolirooleihin ja järjestäytyneeseen yhteiskuntaan laajemmin äärikriittisesti. Ihastunut tyttö kamppailee ihanteidensa ja ihastuksensa välimaastossa. Tilannetta ei auta, että Lauri on tuppisuu ja hänen joukkuekaverinsa seksistisiä ääliöitä.

Elokuva osoittautuu satiiriksi, paikoin taide-elokuvan keinoja käyttäväksi tulkinnaksi Suomesta, jossa pojista kasvatetaan jääkiekkoilijoita ja tytöistä jääkiekkoilijoiden edustusvaimoja. Vanhempi sukupolvi - isät ja äidit - esitetään indoktrinoituneina mainitun kaltaiseen yhteiskuntamalliin, jossa seksismin ja konformismin hädin tuskin peittää pintakorea tekopositiivisuus. Julkkisjääkiekkovalmentaja Juhani Tamminen esittää elokuvahahmona karikatyyria julkisuuskuvastaan, mikä tuo ambivalentin sävyn elokuvan teemoihin.

Elokuvan visuaalinen tukeutuminen Suomen luontoon, erityisesti Turun saaristoon, on silmiinpistävän vahvaa. Luonto on myös kamppailun kohde, valtavirran kulttuurille hedonismin ja näyttäytymisen miljöö, aktivistit puolestaan haaveilevat uudesta elämäntavasta puolivillissä ympäristössä. Elokuva ei kuitenkaan tarjoa luontosuhteelle mitään ratkaisua, päinvastoin kuin yhteiskunnallisille arvoille, vahvistaen Suomen luonnon epähistoriallista asemaa. Elokuva on käsitellyistä ainoa, joka pyrkii taide-elokuvalliseen otteeseen.

Avainsanat: sukupuoli-identiteetti, teini-ikä, luonto, jääkiekko, konformismi

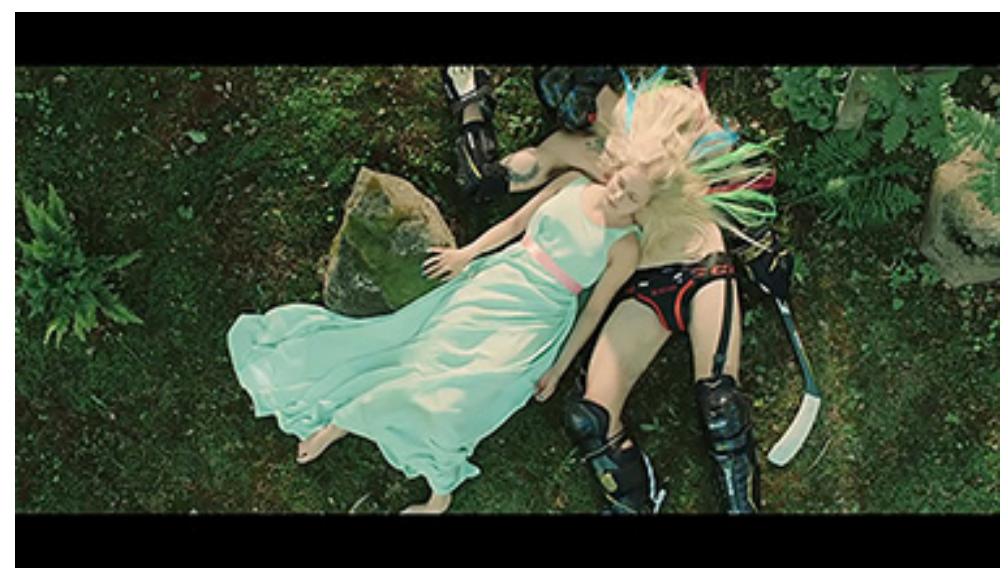

Aktivismia ja sukupuoliroolien purkamista promotoiva Lauri Mäntyvaaran tuuheet ripset hyödyntää taide-elokuvallisia tehokeinoja osana kerrontaa. Kuvakaappaus DVD:Itä.

\section{Muumien taikatalvi}

Elokuva poikkeaa muista artikkelissa käsitellyistä kahdella tapaa: se on animaatio ja sen henkilöt ovat mielikuvitusolentoja kuvitteellisessa maailmassa. Näytelmäelokuvallisuus toteutuu ensi sijassa ääninäyttelijöiden suoritusten kautta. Elokuva käsittelee joka tapauksessa selkeästi suomalais-pohjoismaalaisia kysymyksiä tekoajankohtanaan.

Elokuvassa käy ilmi, että muumit inhoavat talvea ja nukkuvat siksi talossaan läpi talven. Kuvattuna talvena tapahtuu kuitenkin muutos: muumit herätetään nauttimaan talven kauneudesta perinteeseensä kuuluvasta talvenvastaisuudesta huolimatta. Vastentahtoiset muumit alkavat ymmärtää talvisen luonnon kauneutta 
ja mitä kaikkea kivaa lumessa voi kylmyydestä huolimatta tehdä. He ikään kuin astuvat ulos talostaan luontoon, uuteen avarampaan maailmaan.

Elokuvassa on vahva implisiittinen sanoma. Muumit kuulevat, että "joulu" on matkalla Muumilaaksoon. He eivät tiedä, kuka tämä "joulu" on, mutta heidän uteliaisuutensa herää. Käy ilmi, että muumit ovat jossain vaiheessa historiaa hylänneet joulun-Muumipappa esimerkiksi muistaa nähneensä ullakolla kuvan joulukuusesta. Kun joulu saapuu, se saapuu lahjojen muodossa. Ja kun koittaa jouluaterian aika, muumitalolle saapuu yllättäen joukko tuntemattomia olentoja. Muumit kutsuvat nämä vieraikseen joulupöytään ymmärtäen joulun merkityksen. Se on tuntemattomille tulokkaille antaminen, jakaminen.

Avainsanat: luonto, vuoden kiertokulku, perhe, yksinäisyys, suvaitsevaisuus

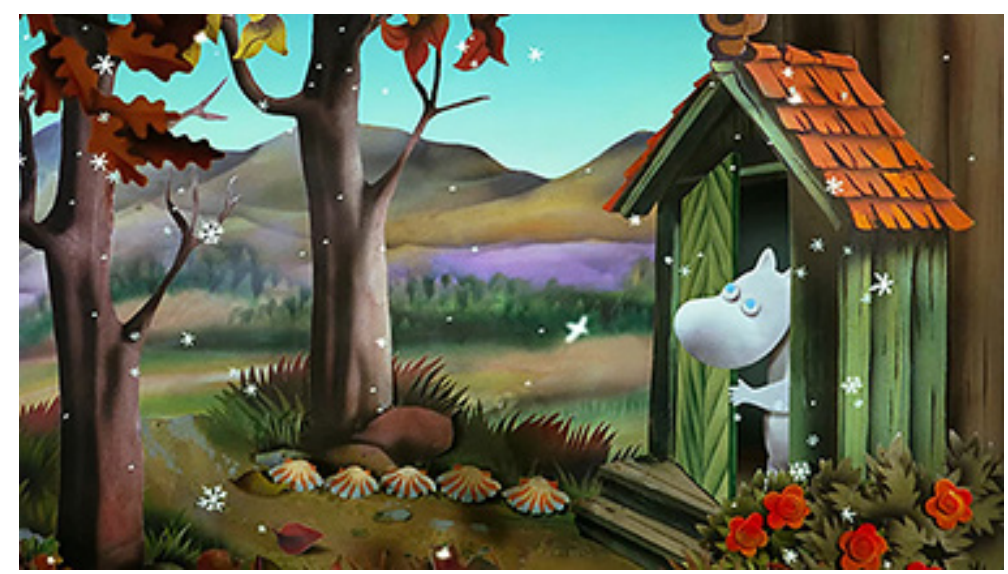

Uusi talvi saapuu Muumilaaksoon ja muuttaa muumien elämän elokuvassa Muumien taikatalvi. Kuvakaappaus DVD:Itä.

\section{Suomen hauskin mies}

Mainoslause: "Huumori on kuolemanvakava asia"

Suomen sisällissotaan sijoittuvassa elokuvassa punakaartin johtoon kuulunut teatterinjohtaja (Martti Suosalo) vangitaan ja lähetetään Helsingin edustalle vankileirille. Leirillä ovat myös ennestään hänen teatterilaisensa, jotka syyttävät häntä pakenemisesta ja alaistensa hylkäämisestä valkoisten vallatessa Helsinkiä. Mies ei kiistä syytöksiä vaan vetoaa tässä hetkessä selviämisen tärkeyteen - teloitukset ovat leirillä rutiininomainen tapahtuma. Myös teatterilaiset tuomitaan kuolemaan, mutta heidät pelastaa viime hetkellä toimeksianto: heidän on valmistettava ja esitettävä huvinäytelmä, jonka avulla leirin komendantti haluaa viihdyttää pian saapuvia saksalaisia vieraita. Teatteriesitys on suksee ja päähenkilö pääsee pakenemaan kohti tuntematonta tulevaisuutta.

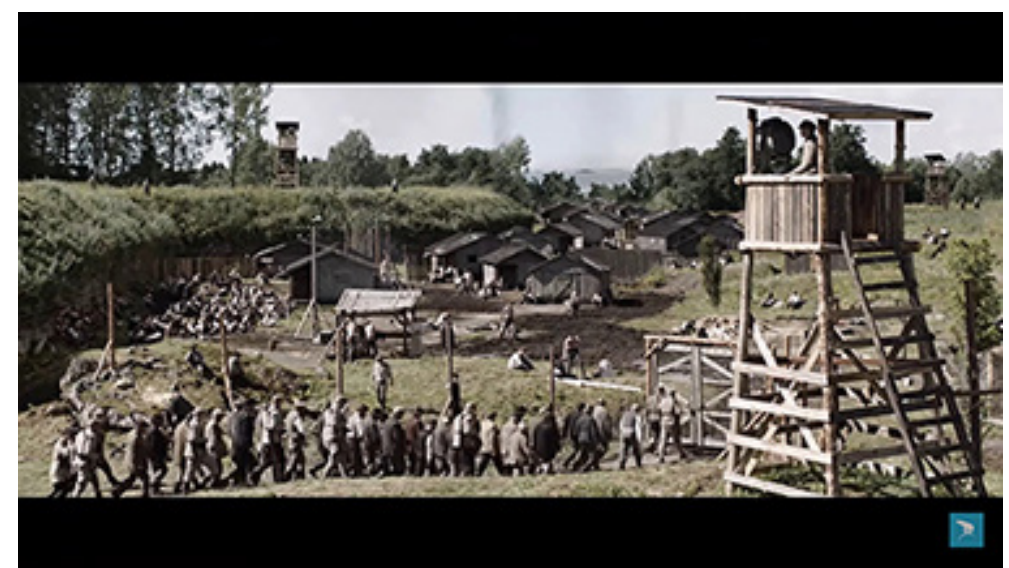

Suomen hauskin mies kertoo sisällissodan jälkeisistä vankileireistä. Kuvakaappaus trailerista. 
Elokuvan sisällissotatulkinta on hyvin tyypillinen 2000-luvun tulkinnoille. Se keskittyy sodan loppuun ja valkoisten vankileireihin ja teloituksiin. Epätyypillisesti punaisen johdon pakeneminen Venäjälle, rivipunaiset hyläten, nostetaan lyhyesti esiin. Sen keskeisin uusinta tulkintasuuntaa mukaileva teema on Saksan rooli sisällissodan lopussa: valkoinen Suomi näyttäytyy halukkaasti vasallin asemaan alistuvana, murhanhimoisena nousukkaana.

Luonto on myös tässä elokuvassa voimakkaasti läsnä. Vankien nurkista kerätyllä lavastuksella tehty teatteriesitys ikään kuin kohoaa luonnonympäristöönsä pala palalta. Vankileiri sijaitsee kauniissa saaristomiljöössä, joka toimii tragedian näyttämönä. Silti luonto on elokuvassa hiljainen turvan ja elinvoiman lähde.

Avainsanat: Suomen sisällissota, nationalismi, fasismi, kolonialismi, näyttämötaide

\section{Toivon tuolla puolen}

Elokuva kertoo hiililaivalla Helsinkiin saapuvan syyrialaispakolaisen (Sherwan Haji) ja helsinkiläisen ravintolayrittäjäksi alkavan suomalaismiehen (Sakari Kuosmanen) tarinan. Miesten kohtaaminen on hyvin symbolinen: ravintoloitsija löytää pakolaisen nukkumasta ravintolansa jäteastioiden takana. Viimeksi mainittu kutsuu turhautuneena paikkaa makuuhuoneekseen. Syntyy nyrkkitappelu, josta alkaa vähäsanainen ja -eleinen ystävyys. Tarina heittelee turvapaikanhakijaa viranomaisilta piileskelystä rasistijengin mukiloitavaksi samalla, kun ravintoloitsija pyrkii saamaan ravintolansa kannattavaksi, jotta hänen työntekijöillään olisi töitä.

Elokuva on hyvin vahvasti Aki Kaurismäen elokuva. Se perustuu 1950-1960-lukujen nostalgisoidulle Helsinki-keskeiselle estetiikalle, jossa kaikki vanha näyttää upouudelta, työläiskotien interiöörit sisustussuunnittelijan työltä ja kaikki puhuvat kirjakieltä. Musiikilla, erityisesti mainittujen vuosikymmenien "kotimaistetulla" rock- ja iskelmämusiikilla on voimakas rooli. Elokuvassa esiintyy Tuomari Nurmion ohella muita tunnettuja ja suurelle yleisölle tuntemattomampia suomalaismuusikoita.

Tähän tuttuun asetelmaan tuodaan sympaattinen pakolaishahmo Lähi-idästä. Nationalistijengien kuvaamisen lisäksi Suomen viranomaisista luodaan erittäin negatiivinen, epäinhimillinen kuva. Elokuvan sanomassa korostuu empatian eetos ja selvä haaste suomalaisille: erilaisuus ja valtaa omaamattomat ovat Suomen alistettu, yhteiskunnallisesti katsoen käyttämätön potentiaali. Viimeksi mainittu on Kaurismäen tuotannon avainteemoja, joten estetiikan ohella myös tässä mielessä elokuva on voimakkaasti auteur-tekijänsä teos.

Avainsanat: turvapaikanhakijat, rasismi, suvaitsevaisuus, luokkayhteiskunta, nostalgia

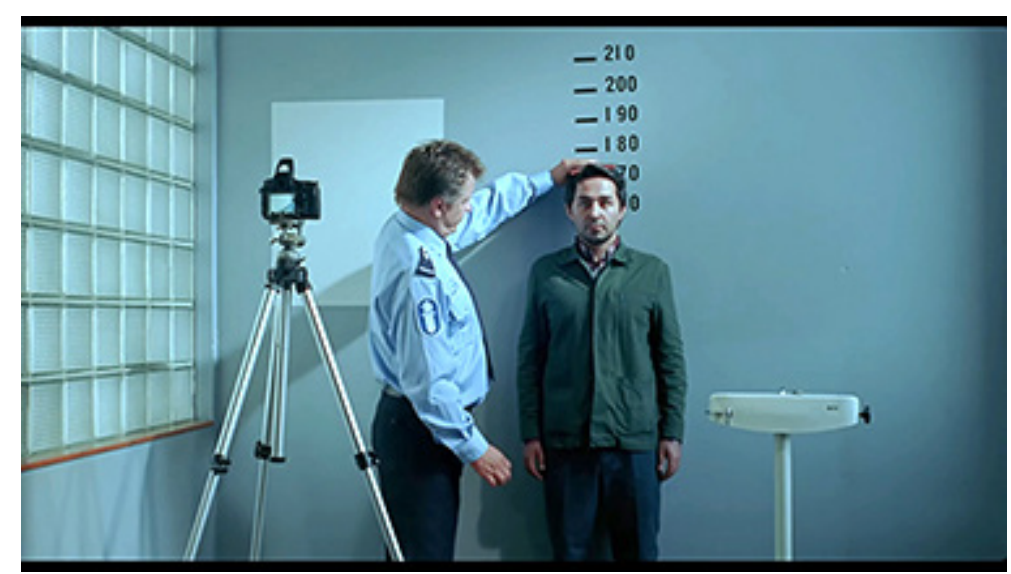

Toivon tuolla puolen kritisoi turvapaikanhakijoiden epäinhimillistävää kohtelua Suomessa. Kuvakaappaus DVD:Itä. 


\section{Tom of Finland}

Mainoslause: "Elokuva rohkeudesta, rakkaudesta ja vapaudesta"

Elokuva kertoo taiteilija Touko Laaksosen (Pekka Strang) tiestä sotavuosien Helsingin ilmapuolustuksen upseerista viranomaisten ahdistelemaksi homoseksuaaliksi ja lopulta kansainväliseksi kulttitaiteilijaksi, "Tom of Finlandiksi". Elokuva on varsin perinteinen historiallinen elämäkertaelokuva, ja se keskittyy vain mainittuun osaan Laaksosen elämästä ja urasta.

Suomi-teeman kannalta on huomattavaa, että elokuva alkaa sotavuosista, suomalaisen historiatietoisuuden kulmakivestä. Sota-aiheiset elokuvat osallistuvat sen määrittelyyn, mitä suomalaisuus oli kansakunnan kohtalonvuosina. Tom of Finland osallistuu tähän keskusteluun räväkällä tavalla. Sen sijaan, että elokuva esittäisi suomalaismiesten homoseksuaaliset suhteet konventionaalisella tavalla, se sisältää otoksen, jossa ilmeisen sivistyneet suomalaisupseerit kokoontuvat joukolla helsinkiläiseen puistoon harrastamaan oraaliseksiä kesken Neuvostoliiton suorittamien pommitusten.

Elokuvan visuaaliselle ilmeelle on alkupuolella ominaista pimeys, öisistä Helsingin kaduista ja puistoista hämäriin interiööreihin, joissa Laaksosta kuulustellaan ja joissa hän alkaa piirtää sittemmin maailmanmaineeseen nousseita teoksiaan. Tämä muuttuu, kun Laaksonen matkustaa Kalifornian aurinkoon, jossa ei ole vain valoisaa ja lämmintä, vaan avoimuus ja suvaitsevaisuus kukoistavat. Allegoria on selkeä.

Avainsanat: homoseksuaalisuus, suvaitsevaisuus, kansainvälisyys, sarjakuva, sotaaika

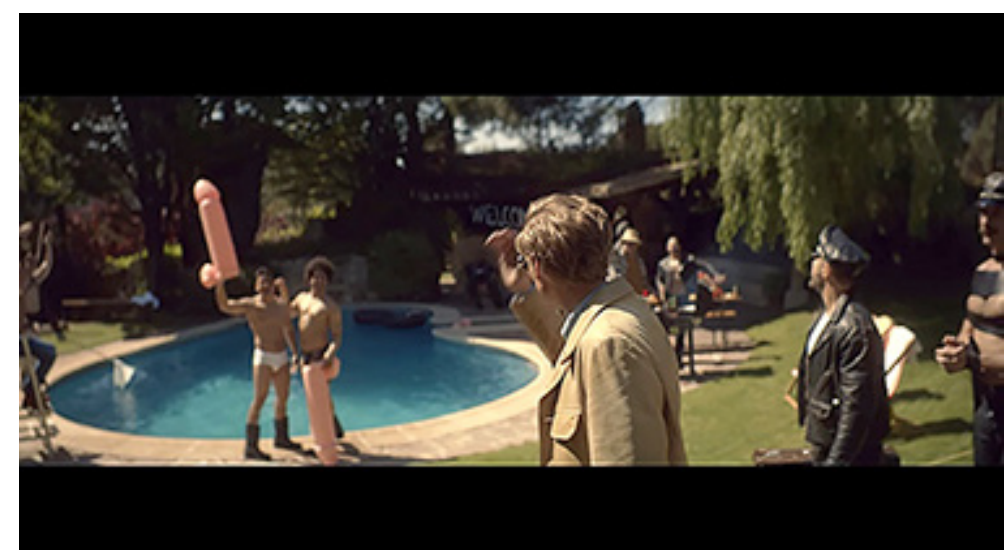

Taiteilija Touko Laaksonen lähtee ahdasmielisestä Suomesta ja löytää kukoistavan homoalakulttuurin Kaliforniasta elokuvassa Tom of Finland. Kuvakaappaus DVD:Itä.

\section{Tuntematon sotilas}

\section{Mainoslause: "Väinö Linnan romaanin pohjalta"}

Tuntemattoman sotilaan tarina, asetelmat ja monet henkilöhahmot ovat tuttuja suurelle määrälle suomalaisia. Niin tuttuja, että kun uutinen kolmannesta filmatisoinnista tuli, hanke tyrmättiin pystyyn. Elokuvaa pidettiin joko aiempien filmatisointien vuoksi turhana ylipäätään tai sitä epäiltiin nationalistisista päämääristä, minkä vuoksi se myös koettiin turhaksi. Miksi penkoa sotaa jälleen kerran?

Kriitikot eivät näyttäneet yhdistävän elokuvahanketta jo pidempään jatkuneeseen sodan uudelleentulkitsemiseen - sota ei todellakaan ole unohdettu aihe suomalaisissa julkisissa keskusteluissa. Tai sitten he, edellä mainitulla tavalla, näkivät elokuvan pyrkivän palauttamaan sodan tulkinnat Linnan romaanin teemojen pariin, pois esimerkiksi naisten tai Suomen natsi-Saksa-suhteen perkaamisesta. 
Aku Louhimiehen versio Tuntemattomasta nostaa kuitenkin juuri näitä teemoja esiin avaten keskushenkilöiden ideologisia taustavaikuttimia ja Suomen yleistä poliittista linjaa, Suomea Itä-Karjalan vapauttajana sekä vahvimmin naisten rooleja ja kokemuksia osana kansakunnan sotaponnisteluja. Elokuva suunnattiin selvästi erikseen myös nuorille, aiheesta ei ehkä lähtökohtaisesti niin kiinnostuneille yleisöille kiinnittämällä rooleihin televisiosta tuttuja esiintyjiä kuten näyttelijä-koomikko Aku Hirviniemi ja laulajatähti Robin.

Elokuvassa luonnon kuvaaminen, representaatio, on esteettis-eksistentiaalisesti hyvin tärkeässä asemassa. Ihmisten mielettömäksi, ilmiselvästi lajinomaiseksi määrittyvä tuhovimma on lopulta vain ohimenevää luonnon kauneuden ja kiertokulun kokonaisuudessa. Kuvasto vaihtelee naturalistisesta kansallisromanttiseen ja kansainvälisiin elokuvaviittauksiin (kuten Gladiator, Ridley Scott, 2000).

Avainsanat: jatkosota, toinen maailmansota, nationalismi, luonto, Suomi

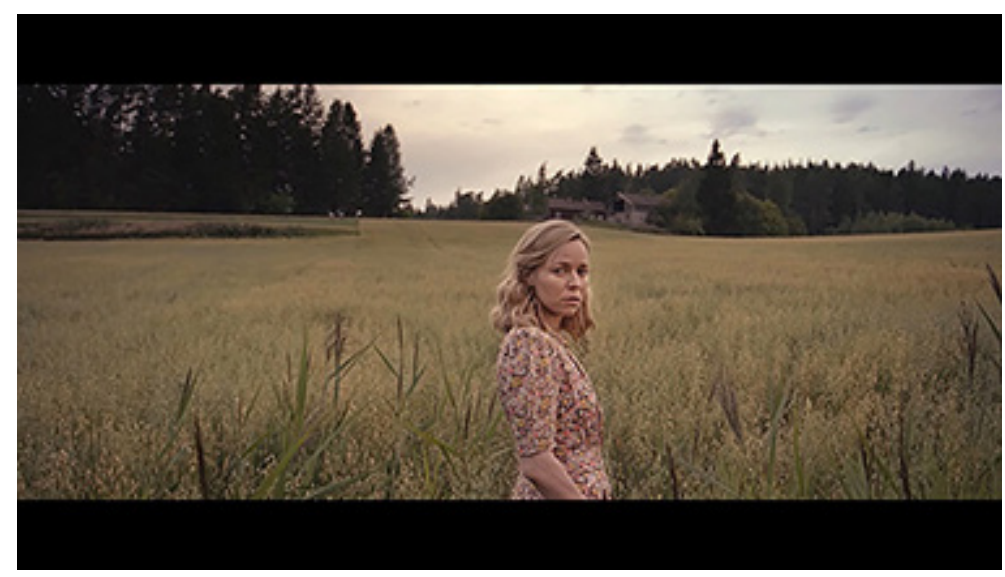

Kolmas Tuntematon sotilas -filmatisointi tuo kotirintaman osaksi suomalaisten sotakokemusten tulkintaa. Kuvakaappaus DVD:Itä.

\section{Lopuksi}

Loin artikkelissa katsauksen Suomi 100 -valtionavustuksella tuettuihin elokuviin. Monista yhtenevistä teemoistaan huolimatta nämä elokuvat eivät muodosta mitään selkeästi hahmottuvaa kokonaisuutta vaan osallistuvat suomalaisuuksien tulkintaan ja rakentamiseen omista näkökulmistaan ja tyyliratkaisuistaan käsin. Keskityin katsauksessa vain näytelmäelokuviin, sillä ne ovat edellä viitatussa (ks. viite 1) hankkeessa minun osa-aluettani. Rahoitusta sai myös viisi dokumenttia. Kooste kaikista rahoitusta saaneista elokuvista on nähtävissä Suomi 100 Finland-YouTube-kanavalla. ${ }^{6}$

Historia ja luonto määrittävät elokuvien perusteella kaikkein eniten suomalaista identiteettiä. Ensin mainittu toimii käyttökelpoisena kiistakapulana, jonka avulla nykyisyyttä - mutta ei niinkään tulevaisuutta - voidaan reflektoida ja pohtia. Suomalainen luonto taas on myytti, jota ihmisen toiminta ei sanottavammin koske - on kuin Suomen luonto orientaatiopisteenä olisi irrallinen ihmisen toiminnasta. Molemmissa kyse on menneisyydestä.

Entä nykyisyys ja tulevaisuus? Suomi 100 -valtiorahoitetut näytelmäelokuvat peräänkuuluttavat suomalaisen yhteiskunnan perusteiden ja asenteiden muutosta, ja avointa suvaitsevaisuutta erilaisuutta kohtaan - tuli tuo erilaisuus sitten sisältä tai ulkopuolelta. Voidaan päätellä, että tämä eetos on myös johtanut juuri näiden elokuvien tukemiseen. Yksikään elokuvista ei kuvaa tai yritä luoda konkreettisia tulevaisuuskuvia. Mutta jokainen niistä viestii omalla tavallaan nimenomaan uuden avoimuuden ja suvaitsevaisuuden löytämisen tarpeesta.

6 Ks. https://www.youtube.com/watch?v=2dDg02a7rGI. Tarkistettu 21.9.2021. 


\section{Lähteet \\ Elokuvat}

95

Ohjaaja: Aleksi Mäkelä.

Käsikirjoittajat: Tatiana Elf, Juha Karvanen, Joona Tena.

Näyttelijät: Jens Hultén, Lauri Tilkanen, Frida Hallgren, Joel Hirvonen, Laura Birn, Samuli Edelmann, Aleksis Koistinen, Mikko Koistinen, Pekka Strang, Jari Virman, Timo Lavikainen, Ylermi Rajamaa, Kalle Lamberg, Samuli Niittymäki.

Tuotantoyhtiö: Yellow Film \& TV Oy, 2017.

\section{Ikitie}

Ohjaaja: AJ Annila.

Käsikirjoittajat: Antti Tuuri, AJ Annila, Aku Louhimies.

Näyttelijät: Tommi Korpela, Sidse Babett Knudsen, Hannu-Pekka Björkman, Irina Björklund, Ville Virtanen, Sampo Sarkola, Eedit Patrakka, Jonna Järnefelt, Antti Virmavirta, Emmi Parviainen, Lembit Ulfsak, Igor Sigov.

Tuotantoyhtiöt: Matila Röhr Productions, Taska Film, Anagram Produktion, Film i Väst, 2017.

Kuudes kerta

Ohjaaja: Maarit Lalli.

Käsikirjoittaja: Maarit Lalli.

Näyttelijät: Pihla Viitala, Antti Luusuaniemi, Anna-Maija Tuokko, Paavo Kinnunen, Arja Saijonmaa, Aksa Korttila, Stig Rästa, Sebastian Rejman, Dick Idman, Minna Haapkylä, Esko Salminen.

Tuotantoyhtiö: Huh huh -filmi oy, 2017.

Lauri Mäntyvaaran tuuheet ripset

Ohjaaja: Hannaleena Hauru.

Käsikirjoittaja: Hannaleena Hauru.

Näyttelijät: Inka Haapamäki, Rosa Honkonen, Santeri Helinheimo Mäntylä.

Tuotantoyhtiö: Oy Aamu ab, 2017.

Muumien taikatalvi

Ohjaaja: Ira Carpelan, Jakub Wronski, Bartosz Wierzbieta.

Käsikirjoittaja: Ira Carpelan, Tove Jansson (alkuteos), Piotr Szczepanowicz, Malgorzata WieckowiczZyla.

Ääninäyttelijät: Vesa Vierikko, Akira Takagi, Oiva Lohtander, Maria Sid, Diandra Flores, Niklas Åkerfelt, Saara Lehtonen, Nina Hukkinen, Terence Scammell.

Tuotantoyhtiö: Oy Filmkompaniet Alpha Ab, Animoon, 2017.

Suomen hauskin mies

Ohjaaja: Heikki Kujanpää.

Käsikirjoittaja: Heikki Kujanpää, Mikko Reitala.

Näyttelijät: Martti Suosalo, Jani Volanen, Leena Pöysti, Paavo Kinnunen.

Tuotantoyhtiö: Inland Film Company Oy, Ljudbang Ab, 2017.

Toivon tuolla puolen

Ohjaaja: Aki Kaurismäki.

Käsikirjoittaja: Aki Kaurismäki.

Näyttelijät: Sherwan Haji, Sakari Kuosmanen, Kaija Pakarinen, Niroz Haji, Janne Hyytiäinen, Ilkka Koivula, Nuppu Koivu, Simon Hussein Al-Bazoon.

Tuotantoyhtiöt: Sputnik Oy, Oy Bufo Ab, 2017. 


\section{Tom of Finland}

Ohjaaja: Dome Karukoski.

Käsikirjoittaja: Aleksi Bardy.

Pekka Strang, Lauri Tilkanen, Jessica Grabowsky, Taisto Oksanen, Seumas Sargent, Jakob Oftebro, Niklas Hogner.

Tuotantoyhtiöt: Helsinki-filmi Oy, Anagram Väst, Fridthjof Film A/S, Neutrinos Productions GmbH, Film i Väst AB, Helsinki Immaterial Oy, 2017.

\section{Tuntematon sotilas}

Ohjaaja: Aku Louhimies.

Käsikirjoittaja: Väinö Linna (alkuteos), Aku Louhimies, Jari Olavi Rantala.

Näyttelijät: Eero Aho, Johannes Holopainen, Jussi Vatanen, Aku Hirviniemi, Hannes Suominen, Paula Vesala, Samuli Vauramo, Joonas Saartamo, Arttu Kapulainen, Andrei Alén, Juho Milonoff, Hannu Ristinen.

Tuotantoyhtiö: Elokuvaosakeyhtiö Suomi 2017, 2017. 